\title{
Willingness to Vaccinate against Coronavirus Disease 2019 and Related Predictors among Non-Healthcare Personnel in Indonesia
}

\author{
Faridah Baroroh ${ }^{1 *}\left(\mathbb{D}\right.$, Ferawati Suzalin ${ }^{2}$, Indriani Indriani ${ }^{3}$, Siti Sangadah ${ }^{4}$, Istiningrum Istiningrum ${ }^{1}$,, Guntur Iham \\ Wahyudi ${ }^{1}$ (D), Muhammad Rayhan Nadhil Rafdilla ${ }^{1}$ (D)
}

${ }^{1}$ Department of Community Pharmacy, Faculty of Pharmacy, Universitas Ahmad Dahlan, Yogyakarta, Indonesia; ${ }^{2}$ Pharmacy Program, Health Polytechnic, Palembang, Indonesia; ${ }^{3}$ Department of Pharmacology and Bioethics, Faculty of Medicine, Alkhairaat University, Palu, Indonesia; ${ }^{4}$ Department of Health, West Papua, Indonesia

Edited by: Sasho Stolesk Citation: Baroroh F, Suzalin F, Indriani I, Sangadah S, Istiningrum I, Wahyudi GI, Rafdilla MRN. Willingness to Vaccinate against Coronavirus Disease 2019 and Relate

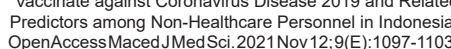
OpenAccess MacedJMedSci. 2021 Nov 12;9(E):1097-1103. Keywords: Predictor; Willingness; Coronavirus Diseas 2019; Vaccine *Correspondence: Faridah Baroroh, Faculty of armacy, Universitas Ahmad Dahlan, Yogyakarta Indonesia. E-mail: faridah@pharm.uad.ac.id Received: 27-Aug-2021 Accepted: 02-Nov-2021 Copyright: ๑ 2021 Faridah Baroroh, Ferawati Suzalin, Indriani Indriani, Siti Sangadah, Istiningrum Istiningrum Guntur Ilham Wahyudi Muhammad Rayhan Nadhil Rafdilla Funding: This study was supported by Universitas Ahmad Competing Interests: The authors have declared that no competing interests exist Open Access: This is an open-access article distributed under the terms or the Creative Commons Attribution-

\begin{abstract}
BACKGROUND: Willingness to vaccinate against coronavirus disease 2019 (COVID-19) among non-healthcare personnel must be increased, considering that breaking the chain of transmission requires $84-90 \%$ herd immunity, with at least $62 \%$ of the vulnerable population vaccinated. However, achieving uptake of recommended vaccination in the targeted population ultimately lies with the community's willingness. This decreasing trend may also be an outcome of a high level of concern over vaccine safety.

AIM: This research was intended to determine the willingness to vaccinate against COVID-19 and its associated factors.

METHODS: It employed a cross-sectional study, and the collected data were analyzed using descriptive analytics and categorical comparison analysis. Two online surveys on Google Forms with non-healthcare personnel as the research subjects were conducted at different times (the first and second stage of vaccination). Screening with inclusion and exclusion criteria yielded 862 respondents spread over 32 provinces in Indonesia.

RESULTS: The results actually showed an increase in willingness to receive the vaccine, from $42.4 \%$ of the respondents in survey $1-55.6 \%$ in survey 2 , and a relationship $(p=0.00)$ between the surveys and this variable. About $36.8-45.3 \%$ were feeling hesitant; the main reason for vaccine hesitancy $(42.2 \%)$ and unwillingness $(43.2 \%)$ was mistrust in the effects or benefits of the vaccine. Although demographic characteristics were not related to the willingness $(p>0.05)$, the opposite was true for the COVID-19 knowledge level (Odds ratio: 1.66; 95\% confidence interval: $1.26-2.18)$.

CONCLUSION: There is an increasing number of people willing to vaccinate against COVID-19 (42.4\% in survey 1 and $55.6 \%$ in survey 2). The time of the survey and COVID-19 knowledge are two predictors $(p=0.00)$ of this willingness.
\end{abstract}

\section{Introduction}

The coronavirus disease 2019 (COVID-19) caused by severe acute respiratory syndrome coronavirus 2 (SARS-CoV-2) has rapidly developed into a pandemic, posing a threat to public health worldwide [1]. Common symptoms at the onset of illness are fever, cough, and fatigue [2], [3]; some have even reported shortness of breath, headache, sore throat, chest pain, nausea, vomiting, diarrhea [4], [5], and abdominal pain [6]. People infected with SARS-CoV-2 can contribute to the spread of infection [7], and those who do not have the symptoms (asymptomatic) can also transmit the disease [8], [9]. Knowledge directly affects attitudes and practice, and trust in efficacy is the most influential and significant factor of preventive behaviors towards COVID-19 [10].

Herd immunity is indirect protection from infectious disease that occurs when a population develops immunity either through vaccination or previous infection. In the context of COVID-19, herd immunity should be achieved through vaccination, as opposed to exposing the population to disease-causing pathogens [11]. Breaking the chain of transmission requires $84-90 \%$ herd immunity [12], with at least $62 \%$ of the vulnerable population vaccinated against COVID19 [13]. The development of a vaccine for SARS-CoV-2 infection is a strategy to overcome the COVID-19 pandemic [14], [15], [16]. An effective vaccine will be beneficial and offer an even greater benefit if used in time to prevent repeated or continuous epidemics [17], [18].

COVID-19 vaccine acceptance in the community in several countries has not reached $70 \%$ [19], [20], while in Indonesia, it is in the range of $45.7-74 \%$ [21]. Lower willingness to be vaccinated can be attributed to increasing concerns about vaccine safety [22]. The public can easily access news from social media about vaccine safety, especially the effects that occur after getting the vaccine. Believing in the conspiracy theories regarding the vaccine 
is positively associated with trusting and relying on social media more than health information providers [23]. Perceptions of vaccine efficacy and willingness to protect others play an essential role in vaccine acceptance [24]. The strategy introduced to achieve vaccination uptake in the targeted population depends on several factors, such as community involvement in health promotion to dispel misconceptions [25]. Furthermore, it is imperative to raise awareness and perception of COVID-19 risk among the community [26], [27]. Vaccine doubts in some countries are upwards of $25 \%$, with the most expressed reason being concerns about the vaccine's safety [28], [29], [30] and efficacy [27]. Some significant predictors of vaccine doubts are sex, education, occupation, income, having children, political affiliation, and perceived threat of COVID-19 infection [31], [32].

When the public can access news about the effects of the COVID-19 vaccine, it is necessary to find out if there is a decrease in the willingness to be vaccinated. The purpose of this study was to determine whether there was a decrease in the willingness to vaccinate against COVID-19 among non-healthcare workers in Indonesia and the factors that are predicted to correlate with it (predictors).

\section{Methods}

This cross-sectional study consisted of two online surveys on Google Forms, with non-healthcare personnel in Indonesia as the research subject. The first survey was conducted from January 28 to 30, 2021, during the first stage of vaccination (January-April 2021, for health workers and public service officers), while the second survey was conducted from May 4 to 10, 2021, during the second stage of vaccination (starting in April 2021, for vulnerable population) [33]. This research has received approval from the Research Ethics Committee of the Faculty of Medicine in Indonesia (No. 1230/C.16/ $\mathrm{FK} / 2021)$.

\section{Research sample and data collection}

The research used multi-stage sampling starting with stratified random sampling to determine which samples would be collected in 34 provinces in Indonesia, followed by purposive sampling for the sample collection. The research samples were the Indonesian community or population who met the inclusion criteria, namely were currently living in Indonesia, aged 18 years and over, had not received the COVID-19 vaccine, and were literate in the Indonesian language. Respondents who were engaging in the healthcare sector as health workers were excluded from the survey. The survey targeted 1000 respondents from the entire 34 provinces in the country to produce the most representative result. Data collection in the first and second surveys was conducted online using Google Form, and the link was sent to the respondents via WhatsApp. This online data collection complies with ethical clearance published by the research ethics committee, and this was to avoid direct face-to-face contact to minimize the risk of exposure to COVID-19.

\section{Data measurement}

The research instrument was a questionnaire consisting of a subject information sheet, Informed Consent, demographic profiles, knowledge of COVID19 and its preventive measures, and willingness to vaccinate against the disease. The questionnaire items concerning COVID-19 knowledge and prevention were developed from the WHO official website [34], while the ones on willingness to receive vaccination referred to similar previous studies [19]. In addition to the subject information sheet and Informed Consent, the questionnaire consists of three aspects: (1) Respondent's demographic profile, that is, gender, age, formal educational attainment, occupation, and family size, (2) knowledge of COVID-19 and preventive measures, comprising ten true or false questions, and (3) willingness to vaccinate against COVID-19 with three response options: willing - hesitant - not willing. It also provides space for respondents to write down the reasons behind their hesitancy and unwillingness.

\section{Data analysis}

The research data were analyzed descriptively and analytically. Descriptive analysis was used to describe data in percentage form, namely demographic characteristics, willingness to be vaccinated, reasons for vaccine hesitancy and unwillingness, and the mean score of COVID-19 knowledge. Meanwhile, the analytical data were analyzed using a categorical comparative test, odds ratio (OR), and confidence interval $(\mathrm{Cl})$. A categorical comparative test with the Chisquare test was carried out to see if the demographic characteristics (i.e., sex, age, education, occupation, and family size), COVID-19 knowledge, and willingness to vaccinate against COVID-19 were related. OR aimed to measure data relationship in the Chi-square test. In the categorical comparative test, data on COVID-19 knowledge were categorized into two: Good (score equal to or higher than 80 ) and bad (lower than 80).

\section{Results}

\section{Demographic profiles}

Of the 1044 respondents, 862 met the inclusion and exclusion criteria and participating in the survey. 
A total of 182 respondents were excluded because 18 respondents were less than 18 years, 28 were health workers, and 136 provided incomplete responses to the questionnaire. The demographic characteristics of the respondents were as follows: $62.9 \%$ female, $56.3 \%$ within the age range of 18-29 years, 53.1\% university graduates, $51.3 \%$ employed, and $60.2 \%$ living in a family of two to four. A total of 623 respondents were involved in survey 1 , and 239 were in survey 2 . Respondents spread across 32 provinces of 34 provinces in Indonesia, from Aceh to West Papua, except North Maluku and Papua.

\section{Willingness to vaccinate against COVID-19 and predictors of willingness to vaccinate against COVID-19}

In survey 1 , the respondents who were hesitant and not willing to be vaccinated were $45.5 \%$ and $12.4 \%$, respectively. Meanwhile, in survey 2 , there were $36.8 \%$ "hesitant" responses and $7.5 \%$ 'unwilling' responses. These results indicate an increase in the willingness to be vaccinated. Moreover, the categorical comparative test confirmed the statistical relationship ( $p=0.000$ ) between the survey and the willingness.

This study described the willingness to vaccinate against COVID-19 based on respondents demographic characteristics and analyzed what factors were related to the willingness. In this case, the predictors were knowledge of the disease and demographic characteristics. Similarly, the previous studies [31], [32] have also predicted the relationship between respondents demographic characteristics (i.e., sex, age, education, employment status, and family size) and vaccine doubts. The Chi-square test of independence included "hesitant" and "unwilling" cell merge to obtain an OR. The analysis results are presented in Table 1. Respondents who were hesitant and unwilling to vaccinate against COVID-19 were asked to include several reasons. Table 2 presents each of the submitted reasons.

\section{COVID-19 knowledge}

Based on the analysis results, there was a relationship ( $p=0.00$ ) between COVID-19 knowledge

Table 1: Willingness to be vaccinated and factors predicted to correlate with the COVID-19 vaccine

\begin{tabular}{|c|c|c|c|c|c|c|c|}
\hline & \multirow[t]{2}{*}{ Total Respondents (\%) } & \multicolumn{3}{|l|}{ Willingness } & \multirow[t]{2}{*}{$p$-value } & & \multirow[t]{2}{*}{ Odds ratio (95\% confidence interval) } \\
\hline & & Willing $\mathrm{n}(\%)$ & $\begin{array}{l}\text { Hesitant } \\
\mathrm{n}(\%)\end{array}$ & Unwilling n (\%) & & & \\
\hline Survey 1 & $623(72.3)$ & $264(42.4)$ & $282(45.3)$ & $77(12.4)$ & $0.000^{*}$ & & $0.59(0.43-0.79)$ \\
\hline Survey 2 & $239(27.7)$ & $133(55.6)$ & $88(36.8)$ & $18(7.5)$ & & & \\
\hline \multicolumn{8}{|l|}{ Knowledge of COVID-19 } \\
\hline Adequate & $483(56.0)$ & $249(51.6)$ & $196(40.6)$ & $38(7.9)$ & \multirow{2}{*}{\multicolumn{2}{|c|}{$0.000^{*}$}} & $1.66(1.26-2.18)$ \\
\hline Poor & 379 (44.0) & $148(39.1)$ & 174 (45.9) & $57(15.0)$ & & & \\
\hline \multicolumn{8}{|l|}{ Demographic characteristics } \\
\hline \multicolumn{8}{|c|}{ Sex } \\
\hline Male & $320(37.1)$ & $151(47.2)$ & $137(42.8)$ & $32(10.0)$ & \multirow{2}{*}{\multicolumn{2}{|c|}{0.732}} & $1.08(0.82-1.42)$ \\
\hline Female & $542(62.9)$ & $246(45.4)$ & $233(43.0)$ & $63(11.6)$ & & & \\
\hline \multicolumn{8}{|l|}{ Age group } \\
\hline $18-29$ (a) & $485(56.3)$ & $211(43.5)$ & $225(46.4)$ & $49(10.1)$ & \multirow[t]{3}{*}{0.118} & $a$ vs $b$ & $0.83(0.62-1.10)$ \\
\hline $30-49$ (b) & $313(36.3)$ & $151(48.2)$ & $121(38.7)$ & $41(13.1)$ & & b vs c & $0.77(0.45-1.33)$ \\
\hline$\geq 50$ (c) & $64(7.4)$ & $35(54.7)$ & $24(37.5)$ & $5(7.8)$ & & a vs $\mathrm{C}$ & $0.64(0.38-1.08)$ \\
\hline \multicolumn{8}{|l|}{ Education } \\
\hline Primary school (a) & $25(2.9)$ & $10(40.0)$ & $12(48.0)$ & $3(12.0)$ & \multirow[t]{3}{*}{0.982} & $a$ vs $b$ & $0.77(0.34-1.78)$ \\
\hline Senior high school (b) & $379(44.0)$ & $175(46.2)$ & $163(43.0)$ & $41(10.8)$ & & b vs c & $0.99(0.76-1.31)$ \\
\hline Higher education (c) & $458(53.1)$ & $212(46.3)$ & 195 (42.6) & $51(11.1)$ & & a vs $\mathrm{C}$ & $0.77(0.34-1.76)$ \\
\hline \multicolumn{8}{|l|}{ Occupation } \\
\hline Employed (a) & $442(51.3)$ & $209(47.3)$ & $176(39.8)$ & 57 (12.9) & \multirow[t]{4}{*}{0.274} & a vs $b^{\star *}$ & \multirow{4}{*}{$\begin{array}{l}1.11(0.85-1.45) \\
(p=0.458)\end{array}$} \\
\hline Homemakers (b) & $103(11.9)$ & $43(41.7)$ & $47(45.6)$ & $13(12.6)$ & & & \\
\hline Students (b) & $267(31.0)$ & $122(45.7)$ & $123(46.1)$ & $22(8.2)$ & & & \\
\hline Unemployed (b) & $50(5.8)$ & $23(46.0)$ & $24(48.0)$ & $3(6.0)$ & & & \\
\hline \multicolumn{8}{|l|}{ Family size } \\
\hline Single (a) & $39(4.5)$ & $18(46.2)$ & $13(33.3)$ & $8(20.5)$ & \multirow[t]{3}{*}{0.319} & $a$ vs $b$ & $0.98(0.51-1.89)$ \\
\hline $2-4$ (b) & $519(60.2)$ & $242(46.6)$ & $225(43.4)$ & $52(10.0)$ & & b vs c & $1.07(0.80-1.42)$ \\
\hline$\geq 5$ (c) & 304 (35.3) & 137 (45.1) & 132 (43.4) & 35 (11.5) & & a vs $\mathrm{c}$ & $1.05(0.54-1.42)$ \\
\hline
\end{tabular}

Table 2: Reasons underlying hesitancy and unwillingness to vaccinate against COVID-19

\begin{tabular}{|c|c|c|c|c|c|c|}
\hline \multirow[t]{2}{*}{ Reasons } & \multicolumn{2}{|l|}{ Survey 1} & \multicolumn{2}{|l|}{ Survey 2} & \multicolumn{2}{|l|}{ Total } \\
\hline & $\begin{array}{l}\text { Hesitant } \\
\mathrm{n}(\%)\end{array}$ & $\begin{array}{l}\text { Unwilling } \\
\mathrm{n}(\%)\end{array}$ & $\begin{array}{l}\text { Hesitant } \\
\mathrm{n}(\%)\end{array}$ & $\begin{array}{l}\text { Unwilling } \\
\mathrm{n}(\%)\end{array}$ & $\begin{array}{l}\text { Hesitant } \\
\mathrm{n}(\%)\end{array}$ & $\begin{array}{l}\text { Unwilling } \\
\mathrm{n}(\%)\end{array}$ \\
\hline $\begin{array}{l}\text { Mistrust in the effects or benefits of the available COVID-19 } \\
\text { vaccine (vaccine efficacy) }\end{array}$ & $131(38.5)$ & $35(35.4)$ & $25(23.4)$ & $6(28.6)$ & $156(34.9)$ & $41(34.2)$ \\
\hline New diseases arise after being vaccinated (vaccine side effects) & $63(18.5)$ & $4(4.0)$ & $30(28.0)$ & $5(23.8)$ & $93(20.8)$ & $9(7.5)$ \\
\hline Fear of needles & 44 (12.9) & $13(13.1)$ & $15(14.0)$ & $4(19.0)$ & $59(13.2)$ & $17(14.2)$ \\
\hline I feel healthy and believe that not everyone is susceptible to COVID-19 & $36(10.6)$ & 16 (16.2) & $12(11.2)$ & $3(14.3)$ & $48(10.7)$ & $19(15.8)$ \\
\hline $\begin{array}{l}\text { There is no clear and detailed public dissemination about the effects and } \\
\text { side effects of the available COVID-19 vaccine }\end{array}$ & $25(7.4)$ & $8(8.1)$ & $7(6.5)$ & & $32(7.2)$ & $8(6.7)$ \\
\hline I believe some contracted COVID-19 despite having been vaccinated & $7(2.1)$ & $7(7.1)$ & $8(7.5)$ & $3(14.3)$ & $15(3.4)$ & $10(8.3)$ \\
\hline The COVID-19 vaccine is not halal & $7(2.1)$ & $3(3.0)$ & $3(2.8)$ & & $10(2.2)$ & $3(2.5)$ \\
\hline A lot of news on social media is unclear and confusing & $7(2.1)$ & & $2(1.9)$ & & $9(2.0)$ & \\
\hline I believe simply boosting my immune system is enough & $7(2.1)$ & $2(2.0)$ & & & $7(1.6)$ & $2(1.7)$ \\
\hline Comorbidities & $2(0.6)$ & $9(9.1)$ & $3(2.8)$ & & $5(1.1)$ & $9(7.5)$ \\
\hline Some are paralyzed and even died after receiving the vaccine & $4(1.2)$ & $1(1.0)$ & $2(1.9)$ & & $6(1.3)$ & $1(0.8)$ \\
\hline There is more than one type of vaccine & $4(1.2)$ & & & & $4(0.9)$ & \\
\hline I believe drinking herbal beverages is enough to prevent COVID-19 & $3(0.9)$ & $1(1.0)$ & & & $3(0.7)$ & $1(0.8)$ \\
\hline
\end{tabular}


and willingness to vaccinate against the disease. Therefore, the research continued to determine if the predictors correlated with COVID-19 knowledge using categorical correlation analysis, that is, the Chi-square test. In this study, a descriptive analysis was conducted to show the average score of respondent's COVID-19 knowledge for each demographic characteristic (i.e., sex, age, education, occupation, and family size). Then, the respondent's demographic characteristics and knowledge of COVID-19 were inputted to the chisquare test of independence. Table 3 shows the factors predicted to correlate with the COVID-19 knowledge.

\section{Discussion}

More respondents in survey 2 (55.6\%) were willing to vaccinate against COVID-19 than survey $1(42.4 \%)$ (Table 1$)$, indicating an increase in the positive attitude toward COVID-19 preventive measures among the non-healthcare personnel from the first to the second stage of vaccination. This is in contrast to a study in Hong Kong [22] where the willingness to receive vaccination decreased from $44.2 \%$ (survey 1 ; a local COVID-19 epidemic broke) to $34.8 \%$ (survey 2; the local epidemic was coming to an end). Willingness to vaccinate against COVID-19 among non-healthcare personnel must be increased, considering that breaking the chain of transmission requires $84-90 \%$ herd immunity [12], with at least $62 \%$ of the vulnerable population vaccinated [13].

There is a significant relationship ( $p=0.000$ ) between knowledge of COVID-19 and willingness to vaccinate against the disease (Table 1). Respondents with a good comprehension of COVID-19 are 1.66 times more likely to be willing than those with lower knowledge scores (OR: 1.66; 95\% Cl: 1.26-2.18). This finding corresponds to a study in Vietnam [35] showing that willingness to receive the vaccine and level of COVID19 knowledge is significantly related, with a 1.2-fold increase in the likelihood of getting the vaccine for a 1-unit increase in the total knowledge score (AOR:1.2; 95\% Cl: 1.1-1.3; $\mathrm{p}<0.0$ ).

Demographic characteristics, that is, sex, age, education level, employment status, and family size, are not predictors of willingness to get the COVID-19 vaccine $(p>0.05)$. Although the willingness in men aged 50 with higher education, employment, and family of two to four is higher than in other groups, there is no relationship between these demographic characteristics and willingness to take the vaccine ( $p>0.05)$. This is in line with [36], which found that women's willingness to receive the vaccine is lower than their male counterparts, and that willingness is higher in people aged 65 and over and those with higher education than the other groups. Similarly, [37] found that the willingness to get the vaccine does not necessarily vary across demographic profiles, that is, $\operatorname{sex}(p=0.429)$ and education level $(p=0.129)$. Research in Brazil [38] also confirms the absence of a statistical relationship $(p>0.05)$ between the number of household members and vaccine doubts.

Results showed 13 reasons for vaccine hesitancy and unwillingness (Table 2), and the most expressed reason was that respondents did not believe in the efficacy of the available vaccines. The secondhighest reason for vaccine hesitancy was the vaccine's side effects, but this is in contrast to the second reason most expressed for unwillingness: respondents feel healthy and think that not everyone is susceptible to COVID-19 infections. Similarly, a previous study in Nepal [39] found that 90 health workers and staff in medical colleges were unwilling to vaccinate against COVID-19; 40 of them have concerns about vaccine safety. Likewise, research in Ethiopia [40] showed that respondents are hesitant to take the vaccine due to concerns about its safety and/or side effects (37\%), followed by doubts about its efficacy (20.7\%), and lack

Table 3: Factors predicted to correlate with the COVID-19 knowledge

\begin{tabular}{|c|c|c|c|c|c|c|c|}
\hline \multirow[t]{2}{*}{ Demographic characteristics } & \multirow{2}{*}{$\begin{array}{l}\text { Total } \\
\text { n (\%) }\end{array}$} & \multicolumn{5}{|c|}{ Knowledge of COVID-19 } & \multirow[t]{2}{*}{ Odds ratio (95\% confidence interval) } \\
\hline & & Mean score & $\begin{array}{l}\text { Poor } \\
(<80)\end{array}$ & $\begin{array}{l}\text { Adequate } \\
(\geq 80)\end{array}$ & $p$-value & & \\
\hline \multicolumn{8}{|l|}{ Sex } \\
\hline Male & $320(37.1)$ & 75.6 & $144(45.0)$ & $176(55.0)$ & \multirow[t]{2}{*}{0.639} & & \multirow{2}{*}{$1.07(0.81-1.41)$} \\
\hline Female & $542(62.9)$ & 76.8 & $235(43.4)$ & $307(56.6)$ & & & \\
\hline \multicolumn{8}{|l|}{ Age range } \\
\hline $18-29$ (a) & $485(56.3)$ & 75.3 & $231(47.6)$ & $254(52.4)$ & \multirow[t]{3}{*}{$0.005^{*}$} & a vs $b$ & $1.57(1.17-2.09)$ \\
\hline $30-49$ (b) & $313(36.3)$ & 78.3 & $115(36.7)$ & $198(63.3)$ & & b vs c & $0.55(0.32-0.94)$ \\
\hline$\geq 50$ (c) & $64(7.4)$ & 74.5 & $33(51.6)$ & $31(48.4)$ & & a vs $\mathrm{c}$ & $0.85(0.51-1.44)$ \\
\hline \multicolumn{8}{|l|}{ Education } \\
\hline Primary school (a) & $25(2.9)$ & 72.0 & $14(56.0)$ & $11(44.0)$ & \multirow[t]{3}{*}{$0.022^{*}$} & $a$ vs $b$ & $1.36(0.60-3.08)$ \\
\hline Senior high school (b) & $379(44.0)$ & 75.5 & $183(48.3)$ & $196(51.7)$ & & b vs $c$ & $1.42(1.08-1.86)$ \\
\hline Higher education (c) & $458(53.1)$ & 77.2 & $182(39.7)$ & $276(60.3)$ & & a vs $\mathrm{c}$ & $1.93(0.86-4.34)$ \\
\hline \multicolumn{8}{|l|}{ Occupation } \\
\hline Employed (a) & $442(51.3)$ & 76.1 & $197(44.6)$ & $245(55.4)$ & \multirow[t]{4}{*}{0.715} & a vs $b^{\star *}$ & \multirow[t]{4}{*}{$1.05(0.80-1.38)$} \\
\hline Homemakers (b) & $103(11.9)$ & 77.2 & $182(43.3)$ & $238(56.7)$ & & & \\
\hline Students (b) & $267(31.0)$ & 76.3 & & & & & \\
\hline Unemployed (b) & $50(5.8)$ & 76.8 & & & & & \\
\hline \multicolumn{8}{|l|}{ Family size } \\
\hline Single (a) & $39(4.5)$ & 74.9 & $18(46.2)$ & $21(53.8)$ & \multirow[t]{3}{*}{0.960} & $a$ vs $b$ & $1.09(0.57-2.10)$ \\
\hline $2-4(b)$ & $519(60.2)$ & 76.5 & $228(43.9)$ & $291(56.1)$ & & b vs c & $1.00(0.76-1.34)$ \\
\hline$\geq 5$ (c) & $304(35.3)$ & 76.2 & $133(43.8)$ & $171(56.3)$ & & a vs $\mathrm{c}$ & $1.10(0.56-2.15)$ \\
\hline
\end{tabular}


of adequate information (12.7\%). Similarly, research in China [41] found that vaccine doubts stem from concerns about the safety of the newly developed vaccine $(60.0 \%)$ and its efficacy $(28.8 \%)$; some question the necessity of vaccination $(7.5 \%)$ and believe that the risk of COVID-19 infections is low (3.7\%).

Many respondents of the age 30-49 (78.3\%) showed higher average scores of COVID-19 knowledge than the other age groups (Table 3). This finding corresponds with a previous study in Indonesia [42], where $71 \%$ of the well-informed respondents are 30-49 years old. There was a significant difference $(p=0.001)$ in knowledge about COVID-19 in the three age groups, similar to a study in Malaysia [43], which also found a significant score difference between age groups. The current research findings indicate that age and COVID-19 knowledge have a significant relationship ( $p=0.005)$, as is the case with a study in Africa [44] that found a significant relationship $(p<0.05)$ between age, education, nationality, background, and the COVID-19 knowledge score. Respondents of the 18-29 age group are 1.57 times more likely to gain less knowledge of COVID-19 than those aged 30-49 (OR:1.57; 95\% Cl: 1.17-2.09). However, in another study [44], respondents of 18-29 years old are 1.4 times more likely to gain better knowledge of COVID-19 than other age groups (95\% Cl: 0.55-0.89; $p=0.004) .0$

Respondents with higher education had a higher COVID-19 knowledge score (77.2) than primary and senior high school education. This is in line with [10], which shows that the level of knowledge is higher in individuals with a higher education level. In addition, there was a significant difference $(p=0.009)$ in the COVID-19 knowledge of the three groups of educational attainment. Results indicate that education level and COVID-19 knowledge are significantly related $(p=0.022)$, where respondents with senior high school education are 1.42 times more likely to have less knowledge than those with higher education (OR:1,42; 95\% Cl: 1.08-1.86). In other words, individuals with a higher level of education have better COVID-19 knowledge. Likewise, a study in Africa [44] found that respondents with senior high school education are 4.7 times more likely (95\% Cl: $0.15-144.7 ; p=0.73$ ) to have better knowledge about COVID-19 than those who never attended formal education. This also applies to education level and age as significant indicators of COVID-19 knowledge [42].

Sex, employment status, and family size are not predictors of COVID-19 knowledge level ( $p>0.05)$, as is the case with the research in Saudi Arabia [45] which concludes that employment status is not a predictor ( $p=0.09$ ) of COVID-19 knowledge. Furthermore, although the knowledge scores were higher among female respondents (76.8) and homemakers (77.2) than in other respondents, there is no statistical difference between the groups ( $p>0.05$ ). Similarly, a study in Saudi Arabia [46] found no statistical difference in the knowledge scores of male and female respondents. Furthermore, a previous study in Indonesia [42] supports this finding, that there is no relationship between sex, marital status, and level of COVID-19 knowledge.

\section{Conclusion}

Knowledge about COVID-19 is a predictor of willingness to vaccinate against the disease (OR: 1.66; 95\% Cl: 1.26-2.18). Based on the knowledge score, many non-healthcare workers have less knowledge of the disease and its preventive measures $(<80)$. Therefore, disseminating accurate information and educating the public about this matter becomes necessary. For educational materials to be readily accepted by non-health workers, especially in terms of prevention, such as the use of drugs and the importance of vaccines, authorities, and relevant stakeholders need to factor in predictors of the knowledge level and decide on the appropriate media of information delivery. The research has found that only half of the respondents (42.4-55.6\%) are willing to get the vaccine, meaning that education alone cannot improve these figures, but this must be supported by positive news about the efficacy and side effects of the COVID-19 vaccine to address reasons for vaccine hesitancy and unwillingness.

\section{Research Limitations}

The number of respondents is not the same in each province, as well as the number of respondents in survey 1 and survey 2 .

\section{Author Contributions}

Conceptualization, F.B.; Methodology, F.B., F.S., In., S.S.; Formal Analysis, F.B., F.S., In., S.S., Is.; Investigation, F.B., F.S., In., S.S., Is., G.I.H., M.R.N.R.; Data Curation, Is., G.I.H., M.R.N.R.; Writing - Original Draft Preparation, F.B., F.S., In., S.S., Is.; Writing Review and Editing, F.S., In., S.S. All authors have carefully read and approved the published version of the manuscript.

\section{Data Availability Statement}

The data used in this study cannot be published for ethical reasons (respondent privacy). 


\section{Institutional Review Board Statement}

The research complies with the research guidelines issued by Universitas Ahmad Dahlan, and the procedure was approved by the Health Research Ethics Committee of the Faculty of Medicine, Duta Wacana Christian University, Indonesia (Ethical Clearance No. 1230/C.16/FK/2021, issued on January 18, 2021).

\section{Acknowledgments}

The authors would like to thank Universitas Ahmad Dahlan as the first author's institution. Special thanks to all participants involved in this study.

\section{References}

1. Wang C, Horby PW, Hayden FG, Gao GF. A novel coronavirus outbreak of global health concern. Lancet (London, England). 2020;395:470-3. https://doi.org/10.1016/ s0140-6736(20)30185-9

PMid:31986257

2. Huang $\mathrm{C}$, Wang Y, Li X, Ren L, Zhao J, Hu Y, et al. Clinical features of patients infected with 2019 novel coronavirus in Wuhan, China. Lancet (London, England). 2020;395(10223):497-506. https://doi.org/10.1016/s0140-6736(20)30183-5

PMid:31986264

3. Ge H, Wang X, Yuan X, Xiao G, Wang C, Deng T, et al. The epidemiology and clinical information about COVID-19. Eur J Clin Microbiol Infect Dis. 2020;39:1011-9. https://doi. org/10.1007/s10096-020-03874-z

PMid:32291542

4. Chen N, Zhou M, Dong X, Qu J, Gong F, Han Y, et al. Epidemiological and clinical characteristics of 99 cases of 2019 novel coronavirus pneumonia in Wuhan, China: A descriptive study. Lancet (London, England). 2020;395(10223):507-13. https://doi.org/10.1016/s0140-6736(20)30211-7 PMid:32007143

5. Guan WJ, Ni ZY, Hu Y, Liang WH, Ou CQ, He JX, et al. Clinical characteristics of coronavirus disease 2019 in China. N Engl J Med. 2020;382:1708-20. https://doi.org/10.1056/ nejmoa2002032

6. Wong SH, Lui RN, Sung JJ. Covid-19 and the digestive system. J Gastroenterol Hepatol. 2020;35(5):744-8. https://doi. org/10.1111/jgh.15047

PMid:32215956

7. Meselson M. Droplets and aerosols in the transmission of SARS-CoV-2. N Engl J Med. 2020;382(21):2063. https://doi. org/10.1056/nejmc2009324

PMid:32294374

8. Johansson MA, Quandelacy TM, Kada S, Prasad PV, Steele M, Brooks JT, et al. SARS-CoV-2 Transmission From People Without COVID-19 Symptoms. JAMA Netw Open. 2021;4:e2035057. https://doi.org/10.1001/jamanetworkopen.2020.35057

\section{PMid:33410879}

9. Widders A, Broom A, Broom J. SARS-CoV-2: The viral shedding vs infectivity dilemma. Infect Dis Health. 2020;25(3):210-5. https://doi.org/10.1016/j.idh.2020.05.002

PMid:32473952

10. Lee M, Kang BA, You M. Knowledge, attitudes, and practices (KAP) toward COVID-19: A cross-sectional study in South Korea. BMC Public Health. 2021;21:295. https://doi.org/10.1186/ s12889-021-10285-y

11. World Health Organization. Coronavirus Disease (COVID-19): Herd Immunity, Lockdowns and COVID-19. Geneva: World Health Organization; 2020. Available from: https://www.who.int/ news-room/q-a-detail/herd-immunity-lockdowns-and-covid-19

12. Kadkhoda K. Herd immunity to COVID-19: Alluring and elusive. Am J Clin Pathol. 2021;155(4):471-2. https://doi.org/10.1093/ ajcp/aqaa272

PMid:33399182

13. Park H, Kim SH. A study on herd immunity of COVID-19 in South Korea: Using a stochastic economic-epidemiological model. Environ Resour Econ. 2020;13:1-6. https://doi. org/10.1007/s10640-020-00439-8

PMid:32836840

14. Liu X, Liu C, Liu G, Luo W, Xia N. COVID-19: Progress in diagnostics, therapy and vaccination. Theranostics. 2020;10(17):7821-35. https://doi.org/10.7150/thno.47987 PMid:32685022

15. Rahman S, Montero MT, Rowe K, Kirton R, Kunik F Jr Epidemiology, pathogenesis, clinical presentations, diagnosis and treatment of COVID-19: A review of current evidence. Expert Rev Clin Pharmacol. 2021;14(5):601-21. https://doi.org $/ 10.1080 / 17512433.2021 .1902303$ PMid:33705239

16. Rodrigues $\mathrm{CM}$, Plotkin SA. Impact of vaccines; health, economic and social perspectives. Front Microbiol. 2020;11:1526. https:// doi.org/10.3389/fmicb.2020.01526 PMid:32760367

17. Petravić L, Arh R, Gabrovec T, Jazbec L, Rupčić N, Zwitter M et al. Factors affecting attitudes towards COVID-19 vaccination: An online survey in slovenia. Vaccines. 2021;9:247. https://doi. org/10.3390/vaccines 9030247

18. Aldila D, Samiadji BM, Simorangkir GM, Khosnaw SH, Shahzad M. Impact of early detection and vaccination strategy in COVID19 eradication program in Jakarta, Indonesia. BMC Res Notes. 2021;14:132. https://doi.org/10.1186/s13104-021-05540-9

19. Reiter PL, Pennell ML, Katz ML. Acceptability of a COVID-19 vaccine among adults in the United States: How many people would get vaccinated? Vaccine. 2020;38:6500-7. https://doi. org/10.1016/j.vaccine.2020.08.043

PMid:32863069

20. El-Elimat $T$, AbuAISamen MM, Almomani BA Al-Sawalha NA, Alali FQ. Acceptance and attitudes toward COVID-19 vaccines: A cross-sectional study from Jordan. PLoS One. 2021;16:e0250555. https://doi. org/10.1101/2020.12.22.20248676 PMid:33891660

21. Ministry of Health of the Republic of Indonesia, ITAGI, UNICEF, WHO. Covid-19 Vaccine Acceptance Survey in Indonesia. The COVID-19 National Task Force; 2020. Available from: https://covid19.go.id/storage/app/media/Hasil\%20Kajian/2020/ November/vaccine-acceptance-survey-id-12-11-2020final.pdf

22. Wang K, Wong EL, Ho KF, Cheung AW, Yau PS, Dong D, et al Change of willingness to accept COVID-19 vaccine and reasons of vaccine hesitancy of working people at different waves of local epidemic in Hong Kong, China: Repeated cross-sectional surveys. Vaccines. 2021;9(1):62. https://doi.org/10.3390/ 
vaccines 9010062

PMid:33477725

23. Viswanath $\mathrm{K}$, Bekalu M, Dhawan D, Pinnamaneni R, Lang J, McLoud R. Individual and social determinants of COVID-19 vaccine uptake. BMC Public Health. 2021;21(1):818. https://doi. org/10.1186/s12889-021-10862-1

PMid:33910558

24. Machida $M$, Nakamura I, Kojima $T$, Saito $R$, Nakaya $T$, Hanibuchi T, et al. Acceptance of a COVID-19 vaccine in Japan during the COVID-19 pandemic. Vaccines. 2021;9(3):210. https://doi.org/10.3390/vaccines9030210 PMid:33802285

25. Wirsiy FS, Nkfusai CN, Ako-Arrey DE, et al. Acceptability of COVID-19 vaccine in Africa. Int J MCH AIDS. 2021;10(1):134-8. https://doi.org/10.21106/ijma.482 PMid:33868778

26. Harapan H, Wagner AL, Yufika A, Winardi W, Anwar S, Gan AK, et al. Acceptance of a COVID-19 Vaccine in Southeast Asia: A Cross-Sectional Study in Indonesia. Front Public Health. 2020;8:381. https://doi.org/10.3389/fpubh.2020.00381 PMid:32760691

27. Almaghaslah D, Alsayari A, Kandasamy G, Vasudevan R. COVID-19 vaccine hesitancy among young adults in Saudi Arabia: A cross-sectional web-based study. Vaccines. 2021;9(4):330. https://doi.org/10.3390/vaccines9040330 PMid:33915890

28. Al-Qerem WA, Jarab AS. COVID-19 vaccination acceptance and its associated factors among a middle Eastern Population. Front Public Health. 2021;9:632914. https://doi.org/10.3389/ fpubh.2021.632914

PMid:33643995

29. Alabdulla M, Reagu SM, Al-Khal A, Elzain M, Jones RM. COVID-19 vaccine hesitancy and attitudes in Qatar: A national cross-sectional survey of a migrant-majority population. Influenza Other Respi Viruses. 2021;15(3):361-70. https://doi. org/10.1111/irv.12847

PMid:33605010

30. Griffith J, Marani H, Monkman H. COVID-19 vaccine hesitancy in Canada: Content analysis of tweets using the theoretical domains framework. J Med Internet Res. 2021;23(4):e26874. https://doi.org/10.2196/26874

PMid:33769946

31. Khubchandani J, Sharma S, Price JH, Wiblishauser MJ, Sharma M, Webb FJ. COVID-19 vaccination hesitancy in the United States: A rapid national assessment. J Community Health. 2021;46(2):270-7. https://doi.org/10.1007/s10900-020-00958-x PMid:33389421

32. Schwarzinger $M$, Watson $V$, Arwidson $P$, Alla $F$, Luchini $S$. COVID-19 vaccine hesitancy in a representative working-age population in France: A survey experiment based on vaccine characteristics. Lancet Public Health. 2021;6:e210-21. https:// doi.org/10.1016/s2468-2667(21)00012-8

33. Ministry of Health of the Republic of Indonesia. Starting in January, here are the Number of Targets for COVID-19 Vaccination in Indonesia. Bureau of Communications and Community Services, Ministry of Health; 2020. Available from: https://sehatnegeriku. kemkes.go.id/baca/umum/20201229/3036076/dimulai-januariberikut-jumlah-sasaran-vaksinasi-covid-19-indonesia

34. World Health Organization. Coronavirus Disease 2019 (COVID-19). Geneva: World Health Organization; 2020. Available from: https://www.who.int/news-room/q-a-detail/ coronavirus-disease-covid-19

35. Huynh G, Nguyen T Van, Nguyen DD, Lam QM, Pham TN, Nguyen HT. Knowledge about COVID-19, beliefs and vaccination acceptance against COVID-19 among high-risk people in Ho Chi Minh City, Vietnam. Infect Drug Resist. 2021;14:1773-80. https://doi.org/10.2147/idr.s308446

PMid:34012276

36. Szilagyi PG, Thomas K, Shah MD, Vizueta N, Cui Y, Vangala S, et al. National trends in the US public's likelihood of getting a COVID-19 vaccine April 1 to December 8, 2020. JAMA. 2021;325(4):396-8. https://doi.org/10.1001/jama.2020.26419 PMid:33372943

37. Faasse K, Newby J. Public perceptions of COVID-19 in Australia: Perceived risk, knowledge, health-protective behaviors, and vaccine intentions. Front Psychol. 2020;11:551004. https://doi. org/10.3389/fpsyg.2020.551004

PMid:33117223

38. de Oliveira BL, Campos MA, de Queiroz RC, de Alves MT, de Souza BF, Dos Santos AM, et al. Prevalence and factors associated with covid-19 vaccine hesitancy in Maranhão, Brazil. Rev Saude Publica. 2021;55():12. https://doi.org/10.11606/ s1518-8787.2021055003417 PMid:33909868

39. Paudel S, Palaian S, Shankar PR, Subedi N. Risk perception and hesitancy toward COVID-19 vaccination among healthcare workers and staff at a medical college in Nepal. Risk Manag Healthc Policy. 2021;14:2253-61. https://doi.org/10.2147/rmhp. s310289

PMid:34104016

40. Zewude B, Habtegiorgis T. Willingness to take COVID-19 vaccine among people most at risk of exposure in Southern Ethiopia. Pragmatic Obs Res. 2021;12:37-47. https://doi. org/10.2147/por.s313991 PMid:34079423

41. Zhou Y, Zhang J, Wu W, Liang M, Wu QS. Willingness to receive future COVID-19 vaccines following the COVID-19 epidemic in Shanghai, China. BMC Public Health. 2021;21(1):1103. https:// doi.org/10.1186/s12889-021-11174-0

PMid:34107930

42. Sulistyawati S, Rokhmayanti R, Aji B, Wijayanti SP, Hastuti SK, Sukesi TW, et al. Knowledge, attitudes, practices and information needs during the COVID-19 pandemic in indonesia. Risk Manag Health Policy. 2021;14:163-75. https://doi.org/10.2147/rmhp. s288579

PMid:33488129

43. Azlan AA, Hamzah MR, Sern TJ, Ayub SH, Mohamad E. Public knowledge, attitudes and practices towards COVID-19: A crosssectional study in Malaysia. PLoS One. 2020;15(5):e0233668. https://doi.org/10.1371/journal.pone.0233668

PMid:32437434

44. Hager E, Odetokun IA, Bolarinwa O, Zainab A, Okechukwu O, Al-Mustapha Al. Knowledge, attitude, and perceptions towards the 2019 coronavirus pandemic: A bi-national survey in Africa. PLoS One. 2021;16:e0247351. https://doi.org/10.1371/journal. pone. 0247351

45. Baig M, Jameel T, Alzahrani SH, Mirza AA, Gazzaz ZJ, Ahmad T, et al. Predictors of misconceptions, knowledge, attitudes, and practices of COVID-19 pandemic among a sample of Saudi population. PLoS One. 2020;15:e0243526. https://doi. org/10.1371/journal.pone.0243526

46. Al-Hanawi MK, Angawi K, Alshareef N, Qattan AM, Helmy HZ, Abudawood $\mathrm{Y}$, et al. Knowledge, attitude and practice toward COVID-19 among the public in the Kingdom of Saudi Arabia: A cross-sectional study. Front Public Health. 2020;8:217. https:// doi.org/10.3389/fpubh.2020.00217

PMid: 32574300 